\title{
Enhancement of Communication Skills of International Language at University Level: Teachers' Side
}

\author{
Tayyaba Zarif
}

Department of Education

Shaheed Benazir Bhutto University

\section{Aziz-u-Nisa}

Department of Education

University of Karachi

\author{
Abdul Nabi \\ Department of Education \\ Shaheed Benazir Bhutto University
}

\begin{abstract}
The primary objective of current research was to study the status of Enhancement of Communication Skills of International Language at University Level it focused on the exploration of problems \& hurdles faced by teachers during teaching \& enhancement of International Language communication skills at. The current study was descriptive in nature and quantitative by method. All those universities of Shaheed Benazirabad which offering International language as Functional and Communicative in the version of applied linguistics as content course to their students in different disciplines were the population of the study. From each University sixty percent of the teachers who were facilitating the course of International Language communication were selected with the help of purposive random sampling. Questionnaire with five point Likert scale was used for collection of data. Data was analyzed in frequencies, percent and mean scores. The study results showed that teachers faced different kinds of problems while facilitating in enhancement of International language communication skills at University level.
\end{abstract}

Keywords: International Language, Communication Skills Enhancement, Learning Level, Existence.

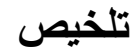

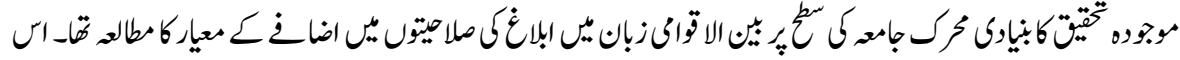

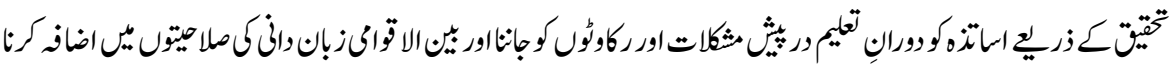

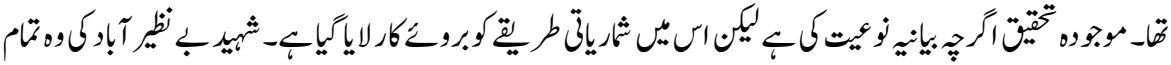

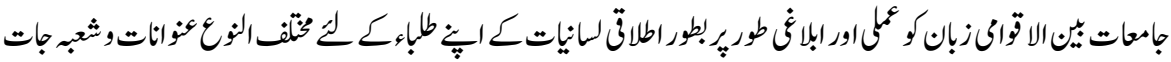




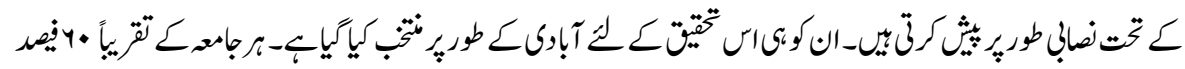

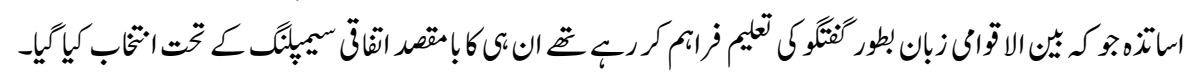

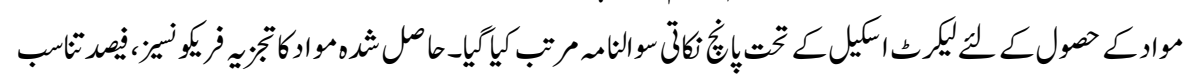

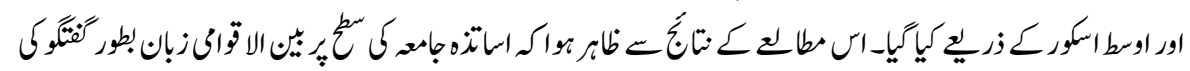

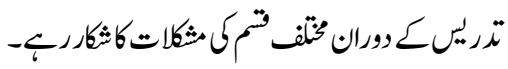

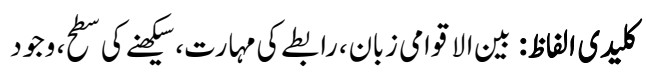

\section{Introduction}

In Pakistan English is used as a co-official language of the state and is used officially in both forms, the written form and the spoken form on national and international occasions (Kachru, 1985;Kachru Y. C., 2006 and Mahmood, 2009)

In Pakistani educational system, the researchers found that the teachers use grammar translation method in the class room. The examination system in education compels the teachers to make students to follow those norms and the ways by which they would be examined. So that the teachers as well as the students can not deviate from those prescribed ways of answering papers in examination resulting the least practice of the English language in the sphere of society (Kjellmer, 1992; Crystal, 1997; Kress, 2000; Milroy, 2002 and Mahmood, 2009).

English in Pakistan is used as official language in civil, bureaucratic and legal bodies run by the government. Consequently the communicative competence of the upcoming generation is very important from primary schools to the university level, for the purpose future demands of International language learning communication competency at university level is very important.

Pakistan is a developing country, faces problems especially in education from primary to its top most level (Tahir, 2012). The universities in Pakistan are granted with financial assistance from Higher Education Commission and collect fees from the students would have sufficient space and conducive environment for better learning out comes. The universities of remote areas (Rural Sindh) face problems in making availability of skilled teachers, students' level of International language learning competence, in and out of class room interaction environment and facilities and consistency by the students in their discipline of studies to work hard. Number of studies point out least teaching and learning outcomes in prevailing international language teaching system where in teacher, taught and administration are equally responsible (Mansoor, 2004;Rahman , 2005; Siddique, 2007)This research is aimed to measure the magnitude of existence of 
problems in four areas such as, the problems faced by the teachers in teaching of International language communication skills due to lack of teaching facilities, due to students level of learning, Pedagogical problems in teaching of International language communication skills and lack of teachers continuous professional development at university level.

\section{Objectives of the Research Study}

1. To study the problems faced by the teachers in teaching of International language communication skills and status of teaching facilities.

2. To study the problems faced by the teachers in teaching of International language communication skills due to students level of learning

3. To study problems faced by the teachers during execution of teaching strategies in teaching process of International language communication skills.

4. To find out the problems faced by the teachers in teaching of International language communication skills \& status of teachers' continuous professional development.

\section{Justifications/ Significance and Importance of Research Work}

The problems faced by the international language teachers while teaching English communication skills are immense and has been vastarea for researchers. Number of studies can be read in research journals. This study focusses on existence and magnitude of problems faced by university teachers of Shaheed Benazirabad Division, Province Sindh. This research and its conclusions will help to either solve or minimize those problems. This study will specially be helpful and beneficial for stakeholders of higher education, Universities and their international language teaching faculty.

\section{Literature Review}

According to the Aitchison, (1981) all over the world, with the passage of time the changes in language can be found on permanent basis. Some languages lose their acceptance and some languages get acceptance as an international language (Higgins, 2003). The same is with English language as well. Norrish, (1997) is of the openion that the English language got acceptance from a tribal language to an International language. It is also being sought that there might be a common global language and most probably that might be English language. It is very clear that the English language has more nonnative speakers than of the native speakers, which indicates that the world is to some extent near to have a common language in the form of English and its global acceptance are accompanied all along to the current era and even for future. That is why the English 
is being spoken and accepted as second language in number of countries and Pakistan is one of them.

Teaching of any language specially English is not an easy job in Pakistan, because it needs to consider number of things, although teaching concerns like students' "background, interest and most appropriate methods of teachings". Though the teachers should provide learning environment for all children like warming up their minds, supportive and comfortable atmosphere and appropriate teaching material for students as can with no trouble understand the topic (Burner, 2015). Burner, (2015)further remarked that "learning setting, the practice and organization of the classroom, the daily plan and practices, and the passionate and social atmosphere, should meet learners' development requirements. It enables learners to feel safe and relaxed. As a result, they are assisted to become liberated and self-reliant students." The management of classroom is prime basis of strain and problematic for both newly and expert teachers. At the same time lack of concentration, others disturbance and dis-obedience are the common behavioral problems of classroom (Farooq, 2015). Farooq, (2015) stated that indifferent attitude can be "any attitude that clearly affects the learners' own learning and other children's learning or responses, or the teacher's ability to operate effectively" as well. Teachers consider it to spend unequal time in dealing with indifferent attitudinal problems as compare with time which spent on teaching of academic activities (Cains, 1996). A common observation is available that students of Asia convey with cultural varieties, methods and technique of learning so are incompletely prepared for critical and analytical thinking in western universities (Kachru Y., 1985) The most important criticism of Asian students is that they don't try to understand the substance and they use rote learning method. They think that teacher or content is only perfect source of knowledge. They don't criticize and also not able to reference correctly due to this they are guilty of plagiarism (Kember, 1991). Chalmers (1997) described that one common misconception about students of South East Asia is that they don't join and work with local students.

Milton (1972) argued that "teachers have little time, to make the students familiar with its specialized language items, or the inclination to avail themselves of the literature.

Gradually universities are developing and implementing training programs to get ready Teacher Assistants for their classroom responsibilities. Some intensive training programs are organized. Various international teaching assistants are educated in different cultural atmosphere and they don't know about particulars of educational settings and interactive teaching approaches employed in classroom (Allen, 1999).

Finally, many ITAs deal with two major hindrances associated with undergraduate education i.e. lack of oral English abilities and differences in cultural expectation(Davis, 1991). It observed that international teaching assistants (ITAs) identify and understand 
more difficulties associated with classroom management. In the light of studies which show that difference of culture had great impact on ITAs instructions (Davis, 1991).Boggs, (1994)noted that "Student gender affected faculty - student interactions." It was noted by Boggs, (1994)that gender has positive impact on pattern of classroom communication. Treichler and Kramarae (1983) noted that female instructors encouraged more students as compare to male instructors and male instructors tended toward more direct in contribution criticism to students. Statham, Richardson (1991) found that female assistant teachers tended to grip management problems by ignoring, indirectly upcoming and reassuring discussions while male teaching assistants were likely more talking to disturb students directly and also use public humiliation as a negative sanction. More teaching experience represented higher levels of self-efficiency toward teaching (Cains, 1996). Shannon (1998) divided teaching experience into three types. 1) Previous TA practice, 2) College teaching practice and 3) K-12 teaching practice. Results showed that teaching assistants with K-12 or college teaching experience were rated more valuable than those who have no such experience. The current researches have highlighted disciplinary dissimilarities in teaching and learning in higher education (Austin, 1996; Stark, 1998). A study conducted by Burner (2015) on EFL Oral Communication Teaching Practices in Serbia, identified four problems, according to them the teachers and the students suffer because of those problems, according to them, a big problem was students with mixed ability in one classroom, overcrowded classes, excessive group works and irrelevant role-play activities. The results of the study of Farooq (2015) suggest that in implementing CLT the teachers face multiple problems according to him the most problematic areas for the teachers are overcrowded classes, least availability of AV aids, low level of learning competency of the learners, and the timing constraints restrict to the teachers to yield better students' learning out comes. A study conducted by Abdulghani (2013) on the necessity for professional development training programs to enhance teaching skills of the faculty members at upper level the results of the study suggest that for institutions to yield better learning out comes, high quality professional training programs for their teaching faculty are mandatory to enhance their capability to compete future world challenge. They further concluded that such professional faculty training programs should focus along with other areas on pedagogical aspects of teaching and learning so that the teacher be equipped to meet current as well as future challenges.

\section{Research Questions}

1. To what extent the problems are faced by the teachers in teaching of International language communication skills due to teaching facilities.

2. Which type of problems are faced by the teachers in teaching of International language communication skills due students' level of learning.

3. What specific problems are faced by the teachers during execution of teaching strategies in teaching of International language communication skills. 
4. How teachers continuous professional development relate with problems which are faced by the teachers in teaching of International language communication skills.

\section{Methodology}

This study is quantitative by method and descriptive by purpose. In this study it was intended to measure the existence and magnitude of problems faced by university teachers in teaching of international language communication skills to the students in the class room. The population of the study was all teachers (permanent and contractual) of public sector universities of Shaheed Benazirabad who are facilitating the teaching of English language \& communication Skills oriented courses. The sample was sixty percent of the population selected by purposive random sampling . For the purpose a selfdeveloped questionnaire with five point Likert scale containing seventeen items was used to collect quantitative data. Expert opinion for validity and reliability of the tool was discussed with two international language teaching experts. To collect the required data, researchers in person visited and administered the tool as per plan, which resulted $85 \%$ return and responses from the sample. The data were analyzed in frequencies, percent and mean scores and descriptively interpreted.

\section{Data analysis}

\section{Section: 1}

Individual analysis of each variable

\begin{tabular}{|c|c|c|c|c|c|c|c|c|}
\hline S. No & Variable/Areas & Statistics & SDA & DA & UD & $\mathbf{A}$ & $\mathbf{S A}$ & Mean \\
\hline 1 & $\begin{array}{l}\text { Provision of an } \\
\text { operation of speakers \& } \\
\text { microphones }\end{array}$ & $\begin{array}{l}\text { Frequency } \\
\text { Percent }\end{array}$ & $\begin{array}{c}\mathrm{N}=0 \\
0 \%\end{array}$ & $\begin{array}{l}\mathrm{N}=2 \\
12 \%\end{array}$ & $\begin{array}{c}2 \\
12 \%\end{array}$ & $\begin{array}{l}\mathrm{N}=4 \\
23 \%\end{array}$ & $\begin{array}{l}\mathrm{N}=9 \\
53 \%\end{array}$ & 4.17 \\
\hline 2 & $\begin{array}{l}\text { Provision of smart } \\
\text { white boards in the } \\
\text { classroom }\end{array}$ & $\begin{array}{l}\text { Frequency } \\
\text { Percent }\end{array}$ & $\begin{array}{c}\mathrm{N}=1 \\
6 \%\end{array}$ & $\begin{array}{l}\mathrm{N}=7 \\
41 \%\end{array}$ & $\begin{array}{l}\mathrm{N}=3 \\
18 \%\end{array}$ & $\begin{array}{l}\mathrm{N}=6 \\
35 \%\end{array}$ & $\begin{array}{c}\mathrm{N}=0 \\
0 \%\end{array}$ & 2.82 \\
\hline 3 & $\begin{array}{l}\text { Appropriateness of } \\
\text { course outlines provided } \\
\text { by university }\end{array}$ & $\begin{array}{l}\text { Frequency } \\
\text { Percent }\end{array}$ & $\begin{array}{c}\mathrm{N}=0 \\
0 \%\end{array}$ & $\begin{array}{l}\mathrm{N}=0 \\
0 \%\end{array}$ & $\begin{array}{l}\mathrm{N}=3 \\
18 \%\end{array}$ & $\begin{array}{l}\mathrm{N}=9 \\
53 \%\end{array}$ & $\begin{array}{l}\mathrm{N}=5 \\
29 \%\end{array}$ & 4.11 \\
\hline 4 & $\begin{array}{l}\text { Use of Library books for } \\
\text { improvement of English }\end{array}$ & $\begin{array}{c}\text { Frequency } \\
\text { Percent }\end{array}$ & $\begin{array}{l}\mathrm{N}=7 \\
41 \%\end{array}$ & $\begin{array}{l}\mathrm{N}=5 \\
29 \%\end{array}$ & $\begin{array}{l}\mathrm{N}=1 \\
6 \%\end{array}$ & $\begin{array}{l}\mathrm{N}=4 \\
24 \%\end{array}$ & $\begin{array}{c}\mathrm{N}=0 \\
0 \%\end{array}$ & 2.11 \\
\hline 5 & $\begin{array}{l}\text { Confidence level of } \\
\text { students to stand in front } \\
\text { of the classmates. }\end{array}$ & $\begin{array}{l}\text { Frequency } \\
\text { Percent }\end{array}$ & $\begin{array}{l}\mathrm{N}=0 \\
0 \%\end{array}$ & $\begin{array}{l}\mathrm{N}=1 \\
6 \%\end{array}$ & $\begin{array}{l}\mathrm{N}=4 \\
23 \%\end{array}$ & $\begin{array}{l}\mathrm{N}=8 \\
47 \%\end{array}$ & $\begin{array}{l}\mathrm{N}=4 \\
24 \%\end{array}$ & 3.88 \\
\hline 6 & $\begin{array}{l}\text { Students' sufficient } \\
\text { vocabulary. }\end{array}$ & \begin{tabular}{|c|} 
Frequency \\
Percent
\end{tabular} & $\begin{array}{c}\mathrm{N}=0 \\
0 \%\end{array}$ & $\begin{array}{c}\mathrm{N}=1 \\
6 \%\end{array}$ & $\begin{array}{l}\mathrm{N}=2 \\
12 \%\end{array}$ & $\begin{array}{l}\mathrm{N}=9 \\
53 \%\end{array}$ & $\begin{array}{l}\mathrm{N}=5 \\
29 \%\end{array}$ & 4.05 \\
\hline
\end{tabular}




\begin{tabular}{|c|c|c|c|c|c|c|c|c|}
\hline 7 & $\begin{array}{l}\text { Fear of criticism on } \\
\text { making mistakes in front } \\
\text { of class by classmates }\end{array}$ & $\begin{array}{l}\text { Frequency } \\
\text { percent }\end{array}$ & $\begin{array}{c}\mathrm{N}=1 \\
6 \%\end{array}$ & $\begin{array}{l}\mathrm{N}=5 \\
29 \%\end{array}$ & $\begin{array}{l}\mathrm{N}=5 \\
29 \%\end{array}$ & $\begin{array}{l}\mathrm{N}=5 \\
29 \%\end{array}$ & $\begin{array}{c}\mathrm{N}=1 \\
6 \%\end{array}$ & 3.00 \\
\hline 8 & $\begin{array}{l}\text { Fear of criticism on } \\
\text { making mistakes by } \\
\text { teachers }\end{array}$ & $\begin{array}{l}\text { Frequency } \\
\text { percent }\end{array}$ & $\begin{array}{c}\mathrm{N}=1 \\
6 \%\end{array}$ & $\begin{array}{l}N=5 \\
29 \%\end{array}$ & $\begin{array}{l}N=5 \\
29 \%\end{array}$ & $\begin{array}{l}\mathrm{N}=5 \\
29 \%\end{array}$ & $\begin{array}{c}\mathrm{N}=1 \\
6 \%\end{array}$ & 3.00 \\
\hline 9 & $\begin{array}{l}\text { Students' classroom } \\
\text { interaction }\end{array}$ & $\begin{array}{l}\text { Frequency } \\
\text { Percent }\end{array}$ & $\begin{array}{c}\mathrm{N}=0 \\
0 \%\end{array}$ & $\begin{array}{l}\mathrm{N}=2 \\
12 \%\end{array}$ & $\begin{array}{l}\mathrm{N}=3 \\
18 \%\end{array}$ & $\begin{array}{l}\mathrm{N}=7 \\
41 \%\end{array}$ & $\begin{array}{l}\mathrm{N}=5 \\
29 \%\end{array}$ & 3.88 \\
\hline 10 & $\begin{array}{l}\text { Word pronunciation } \\
\text { activities }\end{array}$ & $\begin{array}{l}\text { Frequency } \\
\text { Percent }\end{array}$ & $\begin{array}{l}\mathrm{N}=3 \\
18 \%\end{array}$ & $\begin{array}{l}\mathrm{N}=7 \\
41 \%\end{array}$ & $\begin{array}{l}\mathrm{N}=2 \\
12 \%\end{array}$ & $\begin{array}{l}\mathrm{N}=4 \\
24 \%\end{array}$ & $\begin{array}{c}\mathrm{N}=1 \\
6 \%\end{array}$ & 2.58 \\
\hline 11 & $\begin{array}{l}\text { The students' instable } \\
\text { memory }\end{array}$ & $\begin{array}{l}\text { Frequency } \\
\text { Percent }\end{array}$ & $\begin{array}{c}\mathrm{N}=0 \\
0 \%\end{array}$ & $\begin{array}{l}\mathrm{N}=3 \\
18 \% \\
\end{array}$ & $\begin{array}{l}\mathrm{N}=2 \\
12 \% \\
\end{array}$ & $\begin{array}{l}\mathrm{N}=10 \\
59 \% \\
\end{array}$ & $\begin{array}{l}\mathrm{N}=2 \\
12 \%\end{array}$ & 3.64 \\
\hline 12 & $\begin{array}{l}\text { Expectations of teachers } \\
\text { from the students during } \\
\text { usage of teaching } \\
\text { strategies. }\end{array}$ & $\begin{array}{l}\text { Frequency } \\
\text { Percent }\end{array}$ & $\begin{array}{c}\mathrm{N}=1 \\
6 \%\end{array}$ & $\begin{array}{l}\mathrm{N}=2 \\
12 \%\end{array}$ & $\begin{array}{l}\mathrm{N}=3 \\
18 \%\end{array}$ & $\begin{array}{l}\mathrm{N}=7 \\
41 \%\end{array}$ & $\begin{array}{l}\mathrm{N}=4 \\
24 \%\end{array}$ & 3.64 \\
\hline 13 & Absenteeism of students. & $\begin{array}{l}\text { Frequency } \\
\text { Percent }\end{array}$ & $\begin{array}{c}\mathrm{N}=0 \\
0 \%\end{array}$ & $\begin{array}{c}\mathrm{N}=1 \\
6 \%\end{array}$ & $\begin{array}{l}\mathrm{N}=3 \\
18 \% \\
\end{array}$ & $\begin{array}{l}\mathrm{N}=10 \\
59 \%\end{array}$ & $\begin{array}{l}\mathrm{N}=3 \\
18 \%\end{array}$ & 3.88 \\
\hline 14 & $\begin{array}{l}\text { Planning of } \\
\text { communication based } \\
\text { activities. }\end{array}$ & $\begin{array}{l}\text { Frequency } \\
\text { Percent }\end{array}$ & $\begin{array}{l}\mathrm{N}=2 \\
12 \%\end{array}$ & $\begin{array}{l}\mathrm{N}=3 \\
18 \%\end{array}$ & $\begin{array}{c}\mathrm{N}=1 \\
6 \%\end{array}$ & $\begin{array}{l}\mathrm{N}=8 \\
47 \%\end{array}$ & $\begin{array}{l}\mathrm{N}=3 \\
18 \%\end{array}$ & 3.41 \\
\hline 15 & $\begin{array}{l}\text { Training courses for } \\
\text { effective language } \\
\text { teaching }\end{array}$ & $\begin{array}{l}\text { Frequency } \\
\text { Percent }\end{array}$ & $\begin{array}{c}\mathrm{N}=0 \\
0 \%\end{array}$ & $\begin{array}{l}\mathrm{N}=2 \\
12 \%\end{array}$ & $\begin{array}{l}\mathrm{N}=4 \\
24 \%\end{array}$ & $\begin{array}{l}\mathrm{N}=8 \\
47 \%\end{array}$ & $\begin{array}{l}\mathrm{N}=3 \\
18 \%\end{array}$ & 3.70 \\
\hline 16 & $\begin{array}{l}\text { Essence of refresher } \\
\text { courses for teachers }\end{array}$ & $\begin{array}{l}\text { Frequency } \\
\text { Percent }\end{array}$ & $\begin{array}{c}\mathrm{N}=0 \\
0 \%\end{array}$ & $\begin{array}{l}\mathrm{N}=1 \\
6 \%\end{array}$ & $\begin{array}{l}\mathrm{N}=2 \\
12 \%\end{array}$ & $\begin{array}{l}\mathrm{N}=8 \\
47 \%\end{array}$ & $\begin{array}{l}\mathrm{N}=6 \\
35 \%\end{array}$ & 4.11 \\
\hline 17 & $\begin{array}{l}\text { Need of training/ } \\
\text { refresher. }\end{array}$ & $\begin{array}{c}\text { Frequency } \\
\text { Percent }\end{array}$ & $\begin{array}{c}\mathrm{N}=0 \\
0 \%\end{array}$ & $\begin{array}{c}\mathrm{N}=0 \\
0 \%\end{array}$ & $\begin{array}{l}\mathrm{N}=2 \\
12 \%\end{array}$ & $\begin{array}{l}\mathrm{N}=6 \\
35 \%\end{array}$ & $\begin{array}{l}\mathrm{N}=9 \\
53 \%\end{array}$ & 4.41 \\
\hline
\end{tabular}

Section 2

Analysis of research question

\begin{tabular}{|c|c|c|c|c|c|c|c|c|}
\hline S. No & Area & Statistics & SDA & DA & UD & $\mathbf{A}$ & SA & Mean \\
\hline 1 & $\begin{array}{l}\text { Lack of teaching facilities. } \\
\text { (item No: } 1 \text { to } 4 \text { ) }\end{array}$ & $\begin{array}{c}\text { Frequency } \\
\text { Percent }\end{array}$ & $\begin{array}{l}\mathrm{N}=8 \\
12 \%\end{array}$ & $\begin{array}{l}\mathrm{N}=14 \\
21 \%\end{array}$ & $\begin{array}{l}\mathrm{N}=9 \\
13 \%\end{array}$ & $\begin{array}{l}\mathrm{N}=23 \\
34 \%\end{array}$ & $\begin{array}{l}\mathrm{N}=14 \\
21 \%\end{array}$ & 3.75 \\
\hline 2 & $\begin{array}{l}\text { Students' level of learning. } \\
\text { (item No: } 5 \text { to } 8 \text { ) }\end{array}$ & $\begin{array}{c}\text { Frequency } \\
\text { Percent }\end{array}$ & $\begin{array}{l}\mathrm{N}=2 \\
3 \%\end{array}$ & $\begin{array}{l}\mathrm{N}=12 \\
27 \%\end{array}$ & $\begin{array}{l}\mathrm{N}=16 \\
24 \%\end{array}$ & $\begin{array}{l}\mathrm{N}=27 \\
41 \%\end{array}$ & $\begin{array}{l}\mathrm{N}=11 \\
16 \%\end{array}$ & 3.21 \\
\hline 3 & $\begin{array}{l}\text { To what extent the } \\
\text { problems related to usage } \\
\text { of teaching strategies } \\
\text { (item No: } 9 \text { to } 14 \text { ) }\end{array}$ & $\begin{array}{c}\text { Frequency } \\
\text { Percent }\end{array}$ & $\begin{array}{l}\mathrm{N}=6 \\
6 \%\end{array}$ & $\begin{array}{c}\mathrm{N}=18 \\
18 \%\end{array}$ & $\begin{array}{l}\mathrm{N}=14 \\
14 \%\end{array}$ & $\begin{array}{l}N=46 \\
46 \%\end{array}$ & $\begin{array}{l}\mathrm{N}=18 \\
18 \%\end{array}$ & 3.50 \\
\hline 4 & $\begin{array}{l}\text { Professional development } \\
\text { of teachers. } \\
\text { (item No: } 15 \text { to } 17 \text { ) }\end{array}$ & $\begin{array}{l}\text { Frequency } \\
\text { Percent }\end{array}$ & $\begin{array}{l}\mathrm{N}=0 \\
0 \%\end{array}$ & $\begin{array}{c}\mathrm{N}=3 \\
6 \%\end{array}$ & $\begin{array}{l}\mathrm{N}=8 \\
16 \% \%\end{array}$ & $\begin{array}{l}N=22 \\
43 \%\end{array}$ & $\begin{array}{l}\mathrm{N}=18 \\
35 \%\end{array}$ & 4.07 \\
\hline
\end{tabular}


Section three

Consolidated results

\begin{tabular}{|l|l|c|c|c|c|c|c|c|}
\hline $\begin{array}{l}\text { S. } \\
\text { No: }\end{array}$ & $\begin{array}{l}\text { All variables / } \\
\text { Areas }\end{array}$ & Statistics & SDA & DA & UD & A & SA & Mean \\
\hline 1 & Consolidated & Frequency & $\mathrm{N}=16$ & $\mathrm{~N}=46$ & $\mathrm{~N}=45$ & $\mathrm{~N}=$ & $\mathrm{N}=61$ & 3.57 \\
& results of all items & Percent & $2 \%$ & $16 \%$ & $16 \% \%$ & 121 & $21 \%$ & \\
& & & & & $42 \%$ & & \\
\hline
\end{tabular}

\section{Findings}

The findings of the study show that university teachers face numerous problems while teaching international language communication skills in the class room. The existence and magnitude of the problem in the areas such as; non arrangement of trainings/ refresher courses for international language teaching faculty, lack of confidence in students to stand in front of their classmates, insufficient vocabulary of the students, fear of criticism in the students on making mistakes while speaking in international language communication enhancing class rooms are very high where in the mean score is in between 4.41 to 4.05 . The existence and magnitude of the problem in the areas of students' least interaction in communication enhancing classes, least interest in reading of related books in the library of university, absenteeism of students, the students' instability of memory, students take more time than the expectations of the teachers to understand and demonstrate international language items, planning of communication based activities, and the inappropriate course outlines for communication enhancing skills prescribed by university to enhance international language communication skills are either high or moderate, where in the mean score is in between 3.88 to 3.00. The existence and magnitude of the problem in the areas such as improving students word pronunciation, provision and operation of speakers and microphones and non-availability of advanced smart boards (Electronic and movable) and non-permanent marker pens to teach communication enhancing classes are better as compared to the other areas where in the mean score is in between 2.82 to 2.1. Finding revealed that mostly teaching facilities, level \& back ground of associates are effecting the understating level of communication skills of associates at the university level.

\section{Conclusions}

The study was conducted to measure the existence and magnitude of problems faced by the university teachers while teaching international language communication enhancing classes for the purpose a self-developed questionnaire with five point Likert scale containing seventeen items to cover four areas such as, first Status of facilities, second students level of learning, third the problems faced by the university teachers while teaching international language communication enhancing classes by using different teaching strategies and fourth continuous professional development for teaching of 
international language. The results of all items, research question and consolidated results have diversity and show existence of problem \& status in each area of teaching of international language communication skills enhancing classes in all universities under study. Mainly teaching facilities, level \& back ground of associates are effecting the level of communication skills of associates Teachers are also trying to execute different teaching strategies for enhancement of communication skills of international language since continuous professional development is one of key factor to manipulate the unusual situation in the class room dealing with the individual differences of the associate.

\section{Recommendations}

It is recommended in the light of above findings of the study that students should be encouraged to build up their confidence to stand in front of their classmates, so that there should be no criticism on making mistakes while speaking English by the students, students should be given vocabulary enhancing activities, assignments and an environment to interact with their teachers and class mates. Likely the training/ refresher courses for faculty teachers be arranged with the passage of time. To make the students habitual of reading books in library some book reading assignments be given to the students. The most important is the mentorship of administration, the university should create conducive and learning environment for both teacher and taught providing advanced AV aids etc. for better teaching and learning out comes in the area of international language communication competency.

\section{References}

Abdulghani, A. M. (2013). The Need for Professional Training Programs to Improve Faculty Members Teaching Skills . European Journal of Research on Education, vol.1:2, pp.39-45.

Aitchison, J. (1981). Language change: Progress or decay?. London: Fontana.

Allen, R. R. (1999). Teaching Assistant Strategies: An Introduction to College Teaching, Dubuque, Al: Kendall/Hunt.

Austin, A. E. (1996). Institutional and Developmental Cultures: The Relationship between Teaching and Research. New Directions for Institutional Research, vol.90, pp.57-66.

Becher, T. ( 1994). The Significance of Disciplinary Differences. Studies in Higher Education, vol.19:2, pp.151-161. 
Berrett, D. (2012). Harvard conference seeks to jolt university teaching. Chronicle of Higher Education. Retrieved from http://chronicle.com/article/Harvard-Seeks-toJolt/130683/

Boggs, C. a. (1994). The Role of Gender and Communicative Competence in University Students' Evaluations of Their Teaching Assistants . Paper presented at the Annual Meeting of the Speech Communication Association, New Orleans, LA (ERIC Do.

Burner, D. A. (2015). EFL Oral Communication Teaching Practices: A Close Look at University teachers and A2 Students'Perspectivein Thailand and a Critical Eye from Serbya. English Language Teaching, viii(1).

Cains, R. \&. (1996). Newly Qualified Teachers: A Comparative Analysis of the Perceptions Held by B.Ed. and PGCE-trained Primary Teachers of their Training Routes . Educational Psychology, vol.16, pp.257-270.

Chalmers, D. A. (1997). Common Misconceptions about Students from South-East Asia Studying in Australia" . Higher Education Research and Development, vol.16, pp.87-98.

Chien, C. W. (2014). Pre-service English Teachers' Perceptions and Practice of Field Experience and Professional Learning from Expert Teachers' Mentoring. Teachers and Teaching: theory and practice. doi:10.1080/13540602.2014.953817

Crystal, D. (1997). English as a global language. New York: Cambridge University Press.

Davis, W. E. (1991). International Teaching Assistants and Cultural Differences: Student Evaluations of Rapport, Approachability, Enthusiasm and Fairness.

Farooq, M. U. (2015). Creating a Communicative Language Teaching Environment for Improving Students' Communicative Competance at EFL/EAP University Level. International Educational Studies, viii(4).

GovernmentofPakistan. (2009). Government of Pakistan, National Education Policy 2009, Islamabad: Ministry of Education.

Higgins, C. (2003). Ownership" of English in the Outer Circle: An Alternative to the NSNNS Dichotomy. TESOL Quarterly, vol.37:4, pp.615-644. 
Hussain, S. K. (2011). Managerial Training Needs Assesment of Heads of Secondary schools. Bulletin of Education and Research, vol.33:2.

Kachru, Y. (1985). Discourse analysis, non-native Englishes and second language acquisition research. World Englishes, 4(2), 223-232.

Kachru, Y. (1994). Monolingual bias in SLA research. Tesol Quarterly, 28(4), 795-800.

Kachru, Y. C. (2006). World Englishes in Asian contexts. HongKong: HongKong University Press ; London.

Kember, D. a. (1991). A Challenge to the Anecdotal Stereotype of the Asian Student. Studies in Higher Education, 16. (2), 117-128.

Kjellmer, G. (1992). Grammatical or nativelike? NewDirections in English Language Corpora: Methodology, Results, Software Developments. 329-344.

Kress, G. R. (2000). Early spelling : between convention and creativity. London: Routledge.

Mahmood, M. A. (2009). A Corpus Based Analysis of Pakistani English, Ph.D Thesis.

Mansoor, S. (2004). TEFL in Pakista: Emerging issues. The Journal of Asia TEFL Pp349-374. $I(1)$.

Mansoor, Z. \&. (2015). The Paradigm Shift: Leadership Challenges in the Public Sector Schools in Pakistan. Journal of Education and Practice., vi(19). Retrieved from www.iiste.org

Milroy, J. (2002). The legitimate language: giving a history to English. Alternative histories of English .

Milton, O. (1972). Alternatives to the traditional: How professors teaching and how students learn. . San Francisco: Jossey-Bass.

Norrish, J. (1997). English or English? Attitudes, Local Varieties and English Language Teaching. TESL-EJ, 3(1).

Professors, A. A. (2000). Statement on Graduate Strudents. Retrieved from http://www.aaup.org/AAUP/pubsres/policydocs/contents/statementongraduatestu dents.html 
Shannon, D. M. (1998). TA Teaching Effectiveness: The Impact of Training and Teaching Experience. The Journal of Higher Education, vol.69:4, pp.440-466.

Stark, J. S. (1998). Classifying Professional Preparation Programs . The Journal of Higher Education, vol.69:4, pp.353-383.

Statham, A. R. (1991). Gender and University Teaching: A Negotiated Difference. Albany: State University of New York.

Tahir, A. Q. (2012). Challanges of Classroom Management to Effective Teacher Socialization: A Study of English Teachers. Pakistan Journal of Social Sciences, vol.32:1.

Thompson, R. (1986). Behavioral Problems in Children with Developmental and Learning Disabilities. Cambridge: MIT Press.

Treichler, P. A. (1983). Women's Talk in the Ivory Tower. Communication Quarterly, vol.31:2, pp.118-132.

Prof. Dr. Tayyaba Zarif is Chairperson in the Department of Education, Shaheed Benazir Bhutto University, Shaheed Benazirabad.

Dr. Aziz-u-Nisa is an Assistant Professor in the Department of Education, University of Karachi.

Abdul Nabi is Research Associate in the Department of Education, Shaheed Benazir Bhutto University, Shaheed Benazirabad. 